\title{
Isolated systolic hypertension — evaluation of the scale of the problem among medical students - pilot study
}

\section{Izolowane skurczowe nadciśnienie tętnicze — ocena skali problemu w grupie studentów medycyny — badanie pillotażowe}

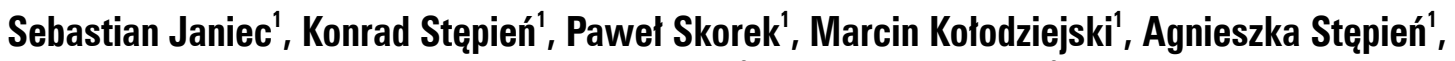 \\ Agnieszka Olszanecka' ${ }^{2}$ Danuta Czarnecka ${ }^{2}$ \\ 'Students' Scientific Group at the Ist Department of Cardiology, Interventional Electrocardiology and Hypertension, \\ Jagiellonian University Medical College, Krakow, Poland \\ ${ }^{2} P^{\text {st }}$ Department of Cardiology, Interventional Electrocardiology and Hypertension, Jagiellonian University Medical College, Krakow, Poland
}

\begin{abstract}
Introduction. Interest in isolated systolic hypertension (ISH) in young people has increased in recent years. The applanation tonometry technique provides new diagnostic opportunities in this group of patients. The aim of the study was to evaluate the incidence of ISH among young adults and factors contributing to its occurrence.

Material and methods. One hundred and two medical students aged 21 to 26 years were examined. The study was based on three peripheral blood pressure measurements and central blood pressure measurement. Information on health status and physical activity was collected using the author-developed questionnaire.

Results. Based on the mean of peripheral blood pressure measurements, hypertension (HT) was detected in 23 students (22.55\%): 18 had ISH, 4 - combined systolic/diastolic HT and 1 - isolated diastolic HT. Pulse wave analysis showed that all individuals with ISH had central blood pressure within the normal range - higher than those without HT, but lower than in the combined systolic/diastolic HT group $(\mathrm{p}<0.001)$. Subjects with ISH were characterized by higher pulse pressure amplitude and lower augmentation index (AIx) compared to those with normal blood pressure.

Subjects with ISH were taller, had a higher body mass index (BMI) and were more likely to have a positive family history of HT compared to normotensives. They also reported more frequent coffee consumption; and $22 \%$ of them used creatine supplements (vs. $0 \%$ in non-HT group).

Conclusions. Measurement of central arterial blood pressure by applanation tonometry should be an integral part of the assessment of young patients with ISH. The study confirmed that ISH patients are characterized by higher growth, weight and physical activity. Further studies are needed to assess the clinical significance of ISH. Key words: applanation tonometry, central blood pressure, isolated systolic hypertension, young adults

Arterial Hypertens. 2017, vol. 21, no. 3, pages: 132-139

DOI: 10.5603/AH.a2017.0018
\end{abstract}

Address for correspondence: Agnieszka Olszanecka, MD, PhD, ${ }^{\text {st }}$ Department of Cardiology, Interventional Electrocardiology and Hypertension, Jagiellonian University Medical College, Krakow, 31-501 Kraków, Kopernika 17 Str, e-mail: agnieszka.olszanecka@uj.edu.pl, phone: + 481242473 00, fax. + 48124247320

V M Copyright @ 2017 Via Medica, ISSN 2449-6170 


\section{Streszczenie}

Wstęp. W ciągu ostatnich lat wzrosło zainteresowanie problemem izolowanego skurczowego nadciśnienia tętniczego (ISH, isolated systolic hypertension) u osób młodych. Metoda tonometrii aplanacyjnej daje w tej grupie nowe możliwości diagnostyczne. Celem pracy była ocena częstości ISH w grupie młodych dorosłych oraz czynników sprzyjających jego występowaniu.

Materiał i metody. Przebadano 102 studentów medycyny w wieku 21-26 lat. Badanie opierało się na trzech pomiarach obwodowego ciśnienia tętniczego oraz pomiarze centralnego ciśnienia tętniczego. Informacje na temat stanu zdrowia oraz aktywności fizycznej zebrano przy użyciu przygotowanej ankiety.

Wyniki. Na podstawie średniej z pomiarów obwodowego ciśnienia tętniczego, nadciśnienie tętnicze (HT) wykryto u 23 studentów (22,55\%): 18 uczestników miało ISH, 4 skurczowo-rozkurczowe HT i 1 izolowane rozkurczowe HT. Analiza fali tętna pokazała, że wszystkie osoby z ISH miały wartości aortalnego ciśnienia tętniczego w granicach normy - wyższe niż u osób bez HT, ale niższe niż w grupie ze skurczowo-rozkurczowym HT ( $p<0,001)$. Osoby z ISH w porównaniu z normotonikami charakteryzowały się wyższą amplifikacją ciśnienia tętna oraz niższym wskaźnikiem wzmocnienia (AIx).

Osoby z ISH w porównaniu z osobami bez HT były wyższe, miały wyższy wskaźnik masy ciała (BMI, body mass index) oraz częściej cechowały się pozytywnym wywiadem rodzinnym w kierunku HT. Częściej deklarowały również spożywanie kawy przynajmniej raz w tygodniu, a 22\% stosowało suplementy kreatyny ( $v .0 \%$ u osób bez HT).

Wnioski. Pomiar centralnego ciśnienia tętniczego metodą tonometrii aplanacyjnej powinien być nieodłącznym elementem oceny młodych pacjentów z ISH. Badanie potwierdziło, że pacjenci z ISH cechują się wyższym wzrostem, masą ciała i aktywnością fizyczną. Kolejne badania konieczne są dla oceny znaczenia klinicznego ISH.

Słowa kluczowe: tonometria aplanacyjna, centralne ciśnienie tętnicze, izolowane skurczowe nadciśnienie tętnicze, młodzi dorośli

\section{Introduction}

Isolated systolic hypertension (ISH) is a specific distinct pathophysiological unit. It is defined as a systolic blood pressure $(\mathrm{SBP}) \geq 140 \mathrm{mmHg}$ and diastolic blood pressure $(\mathrm{DBP})<90 \mathrm{mmHg}$ [1]. Epidemiological studies show that ISH represents a substantial problem in elderly population, with a considerable increase in prevalence with aging. Recently, however, the problem of ISH in the youth gained scientific interest. This problem has been identified with increased frequency, especially in the population of non-smoking tall men with high level of physical activity. The prevalence of ISH in young adults is not well established, although according to available literature it can reach $15 \%$ [2].

The mechanism of ISH varies between younger and older age group. In the elderly, the ISH is associated with increased arterial stiffness. Arterial walls, especially aortic, are prone to mechanical deformities throughout a person's life. As a result, in a person over the age of 60 years a large part of the wall's elastin fibers are damaged. During repair processes they are replaced by new but much more rigid collagen fibers [3]. This results in an increase in the entire vessel's stiffness, that leads to a rise in the amount of secondary reflected waves, which are characterized by greater amplitude and earlier arrival in systole [4]. Finally, these age-related changes lead into an isolated increase in SBP.

In young people, the etiology of the phenomenon of ISH remains not fully elucidated. There are two hypotheses most commonly proposed in the literature to explain the mechanism of ISH in this population. The first refers to the phenomenon of pulse pressure (PP) amplification. This is an escalation of the amplitude of pulse wave propagating to the peripheral arterial tree, proportional to the arterial flexibility. The pulse wave undergoes many modifications, including multiple reflections from the walls of the arteries. The coexistence of increased aortic elasticity and increased body height creates the conditions for a slowly conducted, aggregated reflected wave to reach the diastolic phase of the pulse wave and modify its amplitude by increasing the SBP [5].

The second less frequently described mechanism is an increase in stroke volume (SV) in patients with ISH. The incidence of ISH has been correlated with high physical activity. Regular physical exercises may induce resting bradycardia. In order to maintain the equivalent cardiac output, there is a compensatory increase in the SV. The upsurge of the SV maximiz- 
es the pressure of the blood stream on artery, but the increased flexibility of the vessel compensates for potential aortic pressure changes. In contrast, in peripheral arteries, characterized by greater vascular resistance, there is an increase in SBP [6].

Typically, the occurrence of systolic-diastolic hypertension $(\mathrm{SDH})$ is associated with the development of many organ complications. Contrary to this, ISH in young people can be considered as a physiological, often temporary phenomenon. Nevertheless, the prognostic role of ISH in youth is still questionable. The phenomenon is considered heterogeneous and requires careful global risk and co-existing organ damage assessments $[7,8]$.

The development of knowledge about ISH in recent years would not have been possible without the introduction of a new diagnostic method, the applanation tonometry, which enables the measurement of central blood pressure (cBP). It is now considered a gold standard in research regarding this phenomenon. According to experts, cBP is a better haemodynamic parameter, having a greater importance in the development of atherosclerosis of coronary and cerebral arteries or in the formation of aortic aneurysms [9].

The purpose of this study is to evaluate the scale of the problem of ISH in young adults differentiated in terms of physical activity and to identify factors determining its occurrence.

\section{Materials and methods}

One hundred and two medical students, who responded to the study invitation placed on the internet student forums were included to the study.

Only healthy students weighing more than $50 \mathrm{~kg}$ were qualified. The study protocol was approved by the local ethics committee (Consent No. 122.6120.328.2016).

The participants gave the informed voluntary consent to take part in the study.

All subjects were asked to complete a questionnaire that included questions about personal data, values and regularity of blood pressure measurements at home, family history of hypertension and other cardiovascular diseases, consumption of coffee, energy drinks and performance-enhancing substances.

The level of physical activity was assessed using an original scale based on questions about its type, frequency and duration. In the first question, most popular types of physical activity were taken into account by assigning adequate points ( 3 to 5 ) according to the energy consumption per activity [10]. For the other two questions, the assigned points increased proportionally to the frequency (from 1 to 6) and duration of the activity (from 0.5 to 1.5 ). These three values were multiplied to give the final result which was used to classify students into three groups with low ( $<9$ points), medium (9-14 points) and high ( $\geq$ 15 points) physical activity.

Anthropometric measurements of body height and weight were performed. Body mass index (BMI) was calculated (body weight/(height) $)^{2}$ ).

Peripheral BP measurements were performed with use of the validated classic automated $\mathrm{Omron}^{\circledR} \mathrm{M} 3$ HEM-7200-E device. Three subsequent measurements of peripheral BP on the brachial artery were taken following current guidelines. The measurements were taken in a sitting position, in a silenced room, after 5 minutes of rest [8]. BP was measured on both arms and consecutive reading were taken on the arm with the higher pressure noted. For further analysis three BP readings were averaged.

In the next step, a single cBP measurement was performed using applanation tonometry with a validated SphygmoCor device (AtCor Medical, Pty Ltd, West Ryde, Australia). The measurements were taken according to the manufacturer's recommendations - on the left radial artery, lying down, with minimum 2 minutes interval from the peripheral supine $\mathrm{BP}$ measurement. The curve and the $\mathrm{CBP}$ value were generated automatically by the program, using the pre-set peripheral BP value. After quality control of the single obtained data, cBP, AIx and PP amplification were collected from the final report.

\section{Statistical analysis}

Statistica 12.0 software was used for data management and statistical analysis (StatSoft, Statistica 12.0, Tulsa, Oklahoma, USA). The chi-squared test was used to evaluate the comparisons of qualitative data whereas $t$-student and ANOVA tests for quantitative data. For all tests, the $\mathrm{p}$ value $<0.05$ was considered statistically significant. Logistic regression models were performed in order to determine the odds ratio of the ISH by gender, height, BMI, physical activity and intake of energy drinks. Qualitative data were presented as values and percentages and quantitative data as values with the standard deviation.

\section{Results}

The study included 102 medical students, mean age $22.39 \pm 1.00$ years. Among them, $47(46.08 \%)$ were male and $55(53.92 \%)$ female. SBP was significantly higher in men than women $(136.48 \pm 15.06$ vs. 
Table I. The demographic data and anthropometric parameters in the ISH and NBP groups. Unpaired t-test was applied between ISH and NBP subjects

\begin{tabular}{|l|c|c|c|c|}
\hline & $\begin{array}{c}\text { Total } \\
\mathbf{n}=\mathbf{1 0 2}\end{array}$ & $\begin{array}{c}\text { ISH } \\
\mathbf{n}=\mathbf{1 8}(\mathbf{1 7 . 6 5 \% )}\end{array}$ & $\begin{array}{c}\text { NBP } \\
\mathbf{n}=\mathbf{7 9}(\mathbf{7 7 . 4 5 \% )}\end{array}$ & p value \\
\hline Male $\mathrm{n}(\%)$ & $47(46.08 \%)$ & $15(83.33 \%)$ & $29(36.71 \%)$ & $\mathrm{p}=0.002$ \\
\hline Age $($ years) & $22.39 \pm 1.00$ & $22.50 \pm 0.86$ & $22.33 \pm 1.02$ & $\mathrm{p}>0.05$ \\
\hline BMl $\left[\mathrm{kg} / \mathrm{m}^{2}\right]$ & $22.47 \pm 2.94$ & $24.86 \pm 1.99$ & $21.85 \pm 2.89$ & $\mathrm{p}<0.001$ \\
\hline Weight $[\mathrm{kg}]$ & $68.06 \pm 14.01$ & $80.56 \pm 8.94$ & $65.16 \pm 13.67$ & $\mathrm{p}<0.001$ \\
\hline Height $[\mathrm{cm}]$ & $173.24 \pm 9.16$ & $179.89 \pm 7.27$ & $171.90 \pm 9.08$ & $\mathrm{p}<0.001$ \\
\hline
\end{tabular}

BMI — body mass index, ISH — isolated systolic hypertension, NBP — normal blood pressure

Table II. ISH and NBP group characteristics. The significance of differences between ISH and NBP groups was assessed with the chi-squared test

\begin{tabular}{|l|c|c|c|c|}
\hline & $\begin{array}{c}\text { Total } \\
\mathbf{n}=102\end{array}$ & $\begin{array}{c}\text { ISH } \\
\mathbf{n}=18(17.65 \%)\end{array}$ & $\begin{array}{c}\text { NBP } \\
\mathbf{n}=79(77.45 \%)\end{array}$ & p value \\
\hline Regular physical activity $-\mathrm{n}(\%)$ & $74(72.55 \%)$ & $15(83.33 \%)$ & $56(70.89 \%)$ & $\mathrm{p}>0.05$ \\
\hline Family history of $\mathrm{HT}-\mathrm{n}(\%)$ & $53(51.96 \%)$ & $12(66.67 \%)$ & $38(48.10 \%)$ & $\mathrm{p}>0.05$ \\
\hline Creatine intake $-\mathrm{n}(\%)$ & $4(3.92 \%)$ & $4(22.22 \%)$ & $0(0.00 \%)$ & $\mathrm{p}<0.001$ \\
\hline Regular measurements of BP $-\mathrm{n}(\%)$ & $8(7.84 \%)$ & $3(16.67 \%)$ & $5(6.33 \%)$ & $\mathrm{p}>0.05$ \\
\hline Regularly drinking coffee $-\mathrm{n}(\%)$ & $79(77.45 \%)$ & $61(77.22 \%)$ & $15(83.33 \%)$ & $\mathrm{p}=0.039$ \\
\hline Caffeine energy drinks usage $-\mathrm{n}(\%)$ & $26(25.49 \%)$ & $9(50.00 \%)$ & $17(21.52 \%)$ & $\mathrm{p}=0.014$ \\
\hline
\end{tabular}

$\mathrm{BP}$ - blood pressure, HT — hypertension, ISH — isolated systolic hypertension, NBP — normal blood pressure

Table III. Peripheral blood pressure (BP), central blood pressure (cBP), pulse pressure amplification, $\mathrm{T} 1$ and Alx values in the group with ISH, SDH and NBP. Unpaired t-test was applied between ISH and NBP groups as well as ISH and SDH groups

\begin{tabular}{|c|c|c|c|c|c|}
\hline & $\begin{array}{c}\text { ISH } \\
n=18\end{array}$ & $\begin{array}{c}\text { NBP } \\
n=79\end{array}$ & $\begin{array}{c}\text { p value* } \\
\text { (for ISH-NBP analysis) }\end{array}$ & $\begin{array}{c}\text { SDH } \\
n=4\end{array}$ & $\begin{array}{c}\text { p value } \\
\text { (for ISH-SDH analysis) }\end{array}$ \\
\hline Male n (\%) & $15(83.33 \%)$ & $29(36.71 \%)$ & $p=0,002$ & $3(75.00 \%)$ & NS \\
\hline $\begin{array}{l}\text { BP } \\
\text { Systolic } \\
\text { Diastolic } \\
\text { MAP [mmHg] }\end{array}$ & $\begin{array}{c}150.00 \pm 7.68 \\
74.89 \pm 8.65 \\
99.83 \pm 6.77\end{array}$ & $\begin{aligned} 120.97 & \pm 10.52 \\
71.69 & \pm 7.27 \\
88.03 & \pm 7.50\end{aligned}$ & $\begin{array}{c}p<0.001 \\
N S \\
p<0.001\end{array}$ & $\begin{array}{c}157.83 \pm 7.43 \\
97.83 \pm 2.84 \\
117.71 \pm 1.90\end{array}$ & $\begin{array}{c}\text { NS } \\
p<0.001 \\
p<0.001\end{array}$ \\
\hline $\begin{array}{l}\text { cBP } \\
\text { Systolic } \\
\text { Diastolic [mmHg] }\end{array}$ & $\begin{array}{c}121.67 \pm 6.52 \\
76.50 \pm 8.37\end{array}$ & $\begin{array}{c}103.78 \pm 9.27 \\
73.23 \pm 8.03\end{array}$ & $\begin{array}{c}p<0.001 \\
N S\end{array}$ & $\begin{array}{c}133.00 \pm 3.16 \\
99.75 \pm 4.03\end{array}$ & $\begin{array}{l}p=0.003 \\
p<0.001\end{array}$ \\
\hline $\begin{array}{l}\text { Pulse Pressure } \\
\text { Amplification [mmHg] }\end{array}$ & $29.94 \pm 6.38$ & $18.73 \pm 6.04$ & $p<0.001$ & $24.47 \pm 5.00$ & $p>0.05$ \\
\hline Alx $(\%)$ & $-6.44 \pm 20.23$ & $0.27 \pm 17.96$ & $p>0.05$ & $-4.75 \pm 8.77$ & $p>0.05$ \\
\hline
\end{tabular}

Alx - augmentation index, BP — blood pressure, cBP — central blood pressure, ISH — isolated systolic hypertension, MAP — mean arterial pressure, NBP — normal blood pressure, SDH — systolic-diastolic hypertension

$120.07 \pm 12.70 \mathrm{mmHg}, \mathrm{p}<0.001)$. There were no differences in DBP between gender $(72.85 \pm 10.33$ vs. $74.20 \pm 7.98 \mathrm{mmHg}, \mathrm{p}=0.459$, for men and women respectively).

Using the average of three peripheral BP measurements, 79 students were classified as normotensives (NBP), 18 as ISH, 4 as SDH and only one had isolated diastolic hypertension - this person was excluded from further analyzes (Fig. 1).
In the group of ISH subjects $83 \%$ were men (vs. $37 \%$ in the NBP group, $\mathrm{p}=0.002$ ).

Figure 2 shows the values of peripheral BP in groups classified by diagnoses.

Mean values of DBP in groups with NBP and ISH were comparable $71.69 \pm 7.27$ vs. $74.89 \pm 8.65$ $\mathrm{mmHg}(\mathrm{p}=0.107)$.

Differences in mean SBP between ISH and SDH groups were not statistically significant $150.00 \pm 7.68$ 


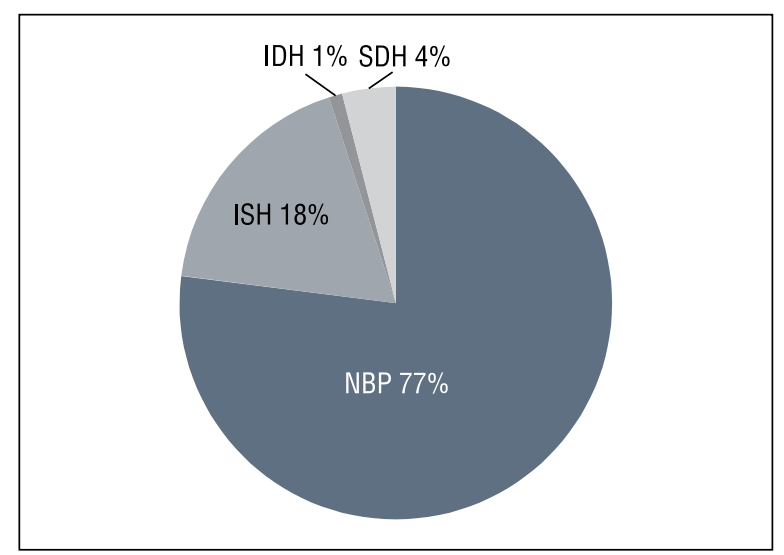

Figure 1. Distribution of blood pressure patterns in the study group. NBP — normal blood pressure; ISH — isolated systolic hypertension; IDH — isolated diastolic hypertension; SDH — systolic-diastolic hypertension

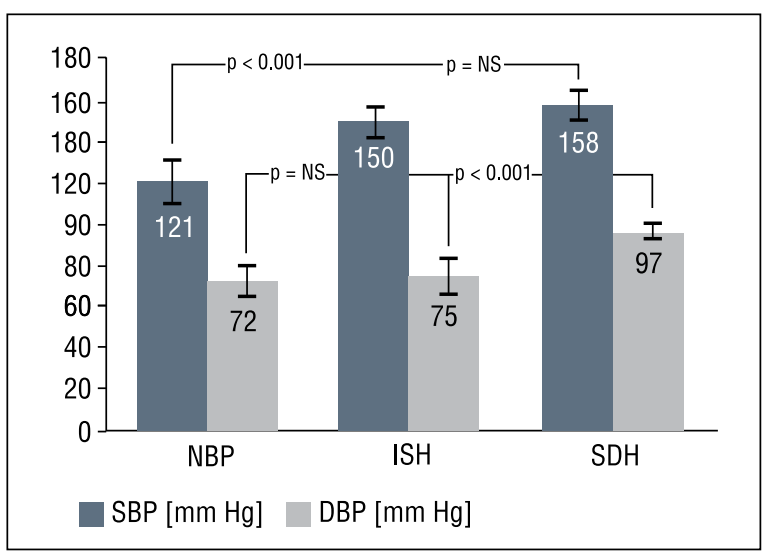

Figure 2. Peripheral systolic and diastolic blood pressure in the groups with normal blood pressure (NBP), isolated systolic hypertension (ISH) and systolic-diastolic hypertension (SDH) [mmHg]. Bars represent standard deviation of the mean. Unpaired t-tests were applied between the groups.

vs. $157.83 \pm 7.43 \mathrm{mmHg}(\mathrm{p}=0.079)$. Comparison of cBP between groups brought other results. ISH students had significantly lower values of cSBP than $\mathrm{SDH}-121.67 \pm 6.52$ vs. $133.00 \pm 3.16 \mathrm{mmHg}$, but higher than NBP $-103.78 \pm 9.27 \mathrm{mmHg}(\mathrm{p}<$ 0.001; for ANOVA) (Fig. 3).

There were no significant differences in cDBP between NBP $(73.23 \pm 8.03 \mathrm{mmHg})$ and ISH groups $(76.50 \pm 8.37 \mathrm{mmHg})(\mathrm{p}=0.125)$. In turn, $\mathrm{SDH}$ were characterized by significantly higher $\mathrm{cDBP}$ than NBP $(99.75 \pm 4.03 \mathrm{mmHg}, \mathrm{p}<0.001)$.

Differences between PP amplification and AIx values have also been analyzed, showing significantly higher PP values in ISH group (Fig. 4).

Regular physical activity was declared by 78 (76.47\%) of the participants, including $56(70.89 \%)$ of the NBP, $15(83.33 \%)$ of the ISH and $3(60.00 \%)$

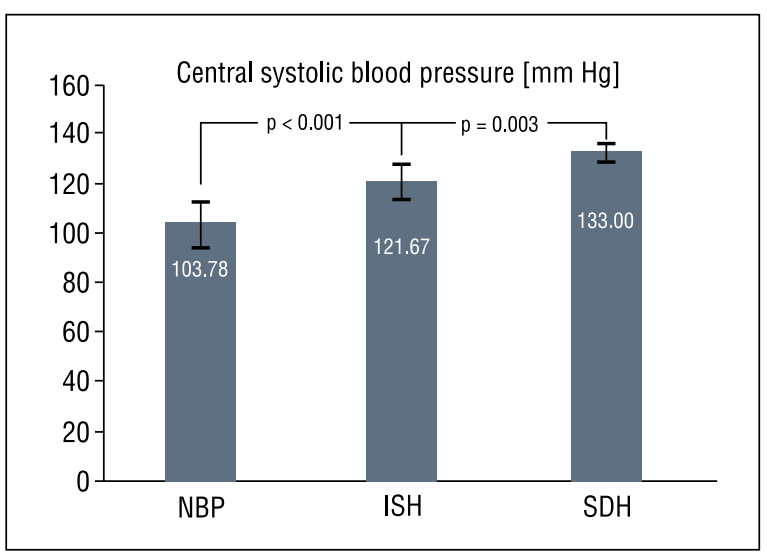

Figure 3. Central systolic blood pressure (cSBP) values in the groups with normal blood pressure (NBP), isolated systolic hypertension (ISH) and systolic-diastolic hypertension (SDH). Bars represent standard deviation of the mean. Unpaired t-tests were applied between the groups. ANOVA for differences between three groups $p<0.001$

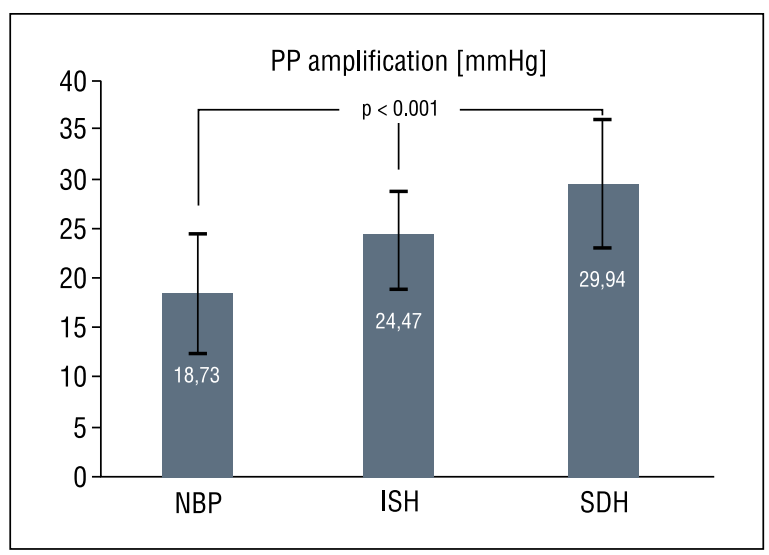

Figure 4. Pulse pressure amplification in the groups with normal blood pressure (NBP), isolated systolic hypertension (ISH) and systolic-diastolic hypertension (SDH). Data were analyzed using ANOVA. Bars represent standard deviation of the mean

of the SDH. For further analyzes, we decided to merge groups with high and medium physical activity $(\geq 9 \mathrm{pts})$, to compare them together with the less active group $(<9 \mathrm{pts})$. The ISH group was characterized by higher physical activity than NBP individuals (77.78\% vs. $55.70 \%$ of those with high or medium physical activity). At the same time, the SDH group was less active than NBP $(40.00 \%$ of those with high or medium physical activity). However, the above data were not statistically significant $(\mathrm{p}=0.156)$.

In our study, ISH subjects were significantly taller than NBP individuals $(179.89 \pm 7.27$ vs. $171.90 \pm$ $9.08 \mathrm{~cm}, \mathrm{p}<0.001)$. Furthermore, ISH individuals had a higher body weight (80.56 \pm 8.94 vs. $65.16 \pm$ $13.67 \mathrm{~kg}, \mathrm{p}<0.001)$ and higher BMI $(24.86 \pm 1.98$ vs. $\left.21.85 \pm 2.89 \mathrm{~kg} / \mathrm{m}^{2}, \mathrm{p}<0.001\right)$ than NBP. Posi- 
tive family history of hypertension in first-degree relatives was reported by $66.67 \%$ of ISH and $48.10 \%$ $\mathrm{NBP}(\mathrm{p}=0.281)$.

The proportion of coffee drinkers (minimum once a week) was higher in ISH group than in NBP (61 $(77.22 \%)$ vs. $15(83.33 \%), \mathrm{p}=0.039)$.

Groups also differed in the consumption of energy drinks containing caffeine. In the ISH group, energy drinks were used at least once a month by 9 $(50.00 \%)$ participants and in the NBP group by 17 $(21.52 \%)$ participants $(\mathrm{p}=0.014)$.

Four students from the studied population admitted to take regularly creatine supplements to improve their physical activity. All of them were in the group of ISH.

The odds ratio of ISH for male gender was 8.6 (95\% CI 2.26-32.8; $\mathrm{p}=0.0002)$, for height above median $(173 \mathrm{~cm}) 7.74(95 \%$ CI 2.03-29.4; $\mathrm{p}=$ $0.004)$, for BMI $>25 \mathrm{~kg} / \mathrm{m}^{2}-4.94(95 \%$ CI $1.5-$ $16.2 ; \mathrm{p}=0.009)$ and use of energy drinks $3.64(95 \%$ CI 1.23-10.76; $\mathrm{p}=0.018)$. Regular physical activity not significantly increased the risk of ISH $(\mathrm{OR}=$ 2.05; 95\% CI 0.53-7.9; $\mathrm{p}=0.26$ ), similarly like positive family history of hypertension $(\mathrm{OR}=2.15$; 95\% CI 0.76-6.4; $\mathrm{p}=0.15$ ).

\section{Discussion}

According to the Polish NATPOL III PLUS study, the prevalence of hypertension in the 18-39 age group was $11 \%$ in men and $3.4 \%$ in women [11]. The epidemiology of ISH in young Polish population is not known. In our study, ISH was detected in 18\% of the studied population, being also the predominant form of hypertension (78\%). These results are comparable to the French study, in which $60 \%$ of young hypertensive men had ISH [12].

Pathogenesis and clinical significance of ISH in young subjects is a controversial issue, still debated in the literature. The ISH problem in young was first noticed by O'Rourke et al. in 2000 [13]. The author proposed the hypothesis of "spurious systolic hypertension". According to it, the ISH is a physiological phenomenon, that results solely from the intensification of normal physiological processes occurring in the body of a young person. In subsequent articles, over the years, this original hypothesis has been repeatedly confirmed, gaining more and more supporters $[2,6]$.

However, there are also opposing voices, suggesting the need of ISH treatment, as it may be a risk factor for cardiovascular complications in the future [14]. Recent study revealed that patients with ISH may have higher risk for cardiovascular diseases and coronary heart disease mortality in long term follow-up compared with those with normal BP [15]. On the other hand, ISH in young was also considered as a form of white-coat hypertension resulting from high sympathetic drive [8].

On the basis of current knowledge, no evidence is available that young ISH subjects benefit from antihypertensive treatment. These individuals can only receive recommendations on lifestyle management [7]. As these evidence are scanty and controversial, young ISH subjects should be followed closely.

In our study ISH students had significantly lower cSBP $(121.67 \pm 6.52 \mathrm{mmHg})$ than SDH. Based on the cutoff point value proposed by Saladini et al. [16] and set at $125 \mathrm{mmHg}$, it can be stated that in the studied population, in patients with ISH the measurement of cSBP was normal despite elevated peripheral SBP. This undoubtedly confirms the importance of applanation tonometry in the diagnosis of ISH in youth and supports the hypothesis that at least in some of these individuals, elevated SBP may have physiological character. Assessment of cBP parameters can prevent patients from misdiagnosis and classification into a group requiring antihypertensive treatment. ISH subjects with normal cBP require only regular monitoring and lifestyle modification [17].

In our study, subjects with ISH were characterized by PP amplification of $29.94 \mathrm{mmHg}$, which was higher than either in the NBP or the SDH group. For comparison, in older people PP amplification is estimated at about $5 \mathrm{mmHg}$ [18]. This observation supports the thesis of the different mechanism of $\mathrm{ISH}$ in youth and underlines its association with increased arterial elasticity.

Moreover, increased PP amplification in young people has been shown to reduce the probability of future cardiovascular complications, while in the elderly, over 50 years old, it is one of the risk factors [19].

In our study ISH participants were mostly males — they constituted $83 \%$ of this group. The increased prevalence of ISH in men has been noted at the beginning of research on this phenomenon. O'Rourke first described ISH in a group consisting of only six men [13]. An important work separately analyzing gender impact on SBP values have been published by Dasgupta et al. [20]. It clearly confirms the significant influence of male gender on SBP in young people - indirectly also on the incidence of ISH in this age group.

We have shown that ISH students were also significantly taller than NBP. The similar effect of body height on $\mathrm{cBP}$ was determined by Rosenwasser et al. [21]. 
The authors of this study suggest a straightforward relationship between height and cSBP.

Body height affects many haemodynamic parameters. This applies to pulse wave velocity (PWV) being the index of arterial stiffness. In subjects with high growth, pulse wave covers much greater distance. Longer conduction of the reflected wave also creates the conditions for its encounter on the diastolic phase of the pulse wave, which explains the increased incidence of ISH [6].

The body weight was another factor influencing the prevalence of ISH in our study. As body weight and height are strongly interrelated, the relationship between body weight and ISH may reflect the above-mentioned influence of high posture on BP. Nevertheless, it should be underlined that obesity is undoubtedly the strongest risk factor for BP elevation, but most cases with obesity-related hypertension present with isolated diastolic hypertension and SDH [22].

We found that BMI in healthy subjects correlates positively with cSBP but not cDBP and thus may be related with increased prevalence of ISH. This association has also been proved in other studies [23]. Furthermore, the body mass is directly related to the arterial stiffness. Complex relationship of BMI and cSBP illustrates the heterogenity of the ISH phenomenon and underlines the need for individual approach to guide the clinical decisions in this group of patients.

Physical activity is also related to ISH in the youth. In our study students with ISH reported higher physical activity than NBP, while SDH were the least active, but contrary to our predictions these differences did not reach statistical significance. This discrepancy may result from relatively small number of subjects included into the pilot study or difficulties in objective quantification of the level of physical activity. Physical activity changes aortic stiffness, which is mostly a positive modification [24], but creates conditions for the development of ISH in some patients. Nevertheless, it is not recommended to limit physical activity in young patients with ISH [6].

In our study, we observed differences in coffee consumption between NBP and ISH. Furthermore, the ISH group was more likely to use energy drinks containing caffeine. It should be noted that the effect of caffeinated energy drinks on peripheral BP is stronger than that caused by pure caffeine [25]. Caffeine also increases the cBP and AIx values [26]. Tolerance on pressor effect of caffeine, that develops in people who regularly consume it may, however, reverse these changes [27]. The importance of caffeine in the development and progression of ISH requires further research.

Interestingly, all participants taking creatine supplements were in the ISH group. Moreover, the rest of the strength training participants, using other supplements, mainly whey protein, were NBP. Creatine supplements are considered by many authors to be safe [28]. However, their influence on the inhibition of physiological increase of parasympathetic system activity, caused by intensive physical activity has been proved [29]. Another study has shown that hyperkinetic circulation, which is one of ISH's mechanisms, may result not only from the sympathetic hyperactivity, but also from the decrease of the parasympathetic activity [30]. The importance of this factor in the development of ISH requires further studies.

\section{Limitations}

The limitation of our pilot study is the relatively small study population. The ISH was diagnosed in 18 and SDH only in 4 persons. Further, large studies are needed.

All participants qualified for the study were medical students. Therefore, the results presented above do not apply to the general population.

According to the guidelines, hypertension can be diagnosed based on the results of at least two measurements made during two different appointments [1]. In our work for organizational reasons they were performed during one visit.

In our study, participants did not have 24-hour blood pressure monitoring (ABPM), which would help to exclude the white coat effect. However, we have made every effort to reduce the stress level as much as possible - the measurements were done by informally dressed people, in a calm and friendly atmosphere, in a suitably adapted room.

\section{Conclusions}

1. ISH is the most common form of hypertension in young population.

2. ISH is more common in men and the factors that determine its occurrence include higher growth and body weight and more frequent use of energy drinks.

3. In all subjects with primarily diagnosed ISH, cBP values remained within the assumed limits, indicating the necessity of promoting the central pressure measurement method in the assessment of young patients with ISH.

4. The prognostic role of ISH is not clearly defined and requires further research. 
Conflicts of interest: None declared.

\section{References}

1. Tykarski A, Narkiewicz K, Gaciong Z, et al. Zasady postępowania w nadciśnieniu tętniczym — 2015 rok. Nadciś Tętn Prakt. 2015; 1(1): 1-70.

2. Mahmud A, Feely J. Spurious systolic hypertension of youth: fit young men with elastic arteries. Am J Hypertens. 2003; 16(3): 229-232, doi: 10.1016/s0895-7061(02)03255-7, indexed in Pubmed: 12620702.

3. Wagenseil JE, Mecham RP. Elastin in large artery stiffness and hypertension. J Cardiovasc Transl Res. 2012; 5(3): 264-273, doi: 10.1007/s12265-012-9349-8, indexed in Pubmed: 22290157.

4. Li JKJ, Zhu Y, O'Hara D, et al. Allometric hemodynamic analysis of isolated systolic hypertension and aging. Cardiovasc Eng. 2007; 7(4): 135-139, doi: $10.1007 / s 10558-007-9040-x$, indexed in Pubmed: 18008162.

5. Avolio AP, Bortel LMV, Boutouyrie P, et al. Role of Pulse Pressure Amplification in Arterial Hypertension: Experts' Opinion and Review of the Data. Hypertension. 2009; 54(2): 375-383, doi: 10.1161/ hypertensionaha.109.134379.

6. Pickering TG. Isolated systolic hypertension in the young. J Clin Hypertens (Greenwich). 2004; 6(1): 47-48, doi: 10.1111/j.15246175.2004.02835.x, indexed in Pubmed: 14724426.

7. Mancia G, Fagard R, Narkiewicz K, et al. 2013 ESH/ESC guidelines for the management of arterial hypertension: the Task Force for the Management of Arterial Hypertension of the European Society of Hypertension (ESH) and of the European Society of Cardiology (ESC). Eur Heart J. 2013; 34(28): 2159-2219, doi: 10.1093/ eurheartj/eht151, indexed in Pubmed: 23771844.

8. Lurbe E, Redon J. Isolated Systolic Hypertension in Young People Is Not Spurious and Should Be Treated: Con Side of the Argument. Hypertension. 2016; 68(2): 276-280, doi: 10.1161/HYPERTENSIONAHA.116.06548, indexed in Pubmed: 27324227.

9. Jankowski P, Bilo G, Kawecka-Jaszcz K. The pulsatile component of blood pressure: its role in the pathogenesis of atherosclerosis. Blood Press. 2007; 16(4): 238-245, doi: 10.1080/08037050701428166, indexed in Pubmed: 17852092.

10. Ainsworth BE, Haskell WL, Leon AS, et al. Compendium of physical activities: classification of energy costs of human physical activities. Med Sci Sports Exerc. 1993; 25(1): 71-80, doi: 10.1249/00005768199301000-00011, indexed in Pubmed: 8292105.

11. Zdrojewski T, Wyrzykowski B, Szczech R, et al. Epidemiology and prevention of arterial hypertension in Poland. Blood Pressure. 2010; 14(sup2): 10-16, doi: 10.1080/08038020500429052.

12. Mallion JM, Hamici L, Chatellier G, et al. Isolated systolic hypertension: data on a cohort of young subjects from a French working population (IHPAF). J Hum Hypertens. 2003; 17(2): 93-100, doi: 10.1038/sj.jhh.1001506, indexed in Pubmed: 12574786.

13. O'Rourke MF, Vlachopoulos C, Graham RM. Spurious systolic hypertension in youth. Vasc Med. 2000; 5(3): 141-145, doi: 10.1177/1358836X0000500303, indexed in Pubmed: 11104296.

14. McEniery CM, Franklin SS, Cockcroft JR, et al. Isolated Systolic Hypertension in Young People Is Not Spurious and Should Be Treated: Pro Side of the Argument. Hypertension. 2016; 68(2): 269-275, doi: 10.1161/HYPERTENSIONAHA.116.06547, indexed in Pubmed: 27324230.

15. Yano Y, Stamler J, Garside DB, et al. Isolated systolic hypertension in young and middle-aged adults and 31-year risk for cardiovascular mortality: the Chicago Heart Association Detection Project in Industry study. J Am Coll Cardiol. 2015; 65(4): 327-335, doi: 10.1016/j. jacc.2014.10.060, indexed in Pubmed: 25634830.
16. Saladini F, Santonastaso M, Mos L, et al. HARVEST Study Group. Isolated systolic hypertension of young-to-middle-age individuals implies a relatively low risk of developing hypertension needing treatment when central blood pressure is low. J Hypertens. 2011; 29(7): 1311-1319, doi: 10.1097/HJH.0b013e3283481a32, indexed in Pubmed: 21659824.

17. O'Rourke MF, Adji A. Guidelines on guidelines: focus on isolated systolic hypertension in youth. J Hypertens. 2013; 31(4): 649-654, doi: $10.1097 / \mathrm{HJH} .0 \mathrm{~b} 013 \mathrm{e} 32835 \mathrm{~d} 8230$, indexed in Pubmed: 23412425.

18. Franklin SS, Khan SA, Wong ND, et al. The relation of blood pressure to coronary heart disease risk as a function of age: the Framingham Heart Study. J Am Coll Cardiol. 2000; 35(Suppl A): 291A-292A.

19. Franklin SS, Larson MG, Khan SA, et al. Does the relation of blood pressure to coronary heart disease risk change with aging? The Framingham Heart Study. Circulation. 2001; 103(9): 1245-1249, doi: 10.1161/01.cir.103.9.1245, indexed in Pubmed: 11238268.

20. Dasgupta K, O'Loughlin J, Chen S, et al. Emergence of sex differences in prevalence of high systolic blood pressure: analysis of a longitudinal adolescent cohort. Circulation. 2006; 114(24): 2663-2670, doi: 10.1161/CIRCULATIONAHA.106.624536, indexed in Pubmed: 17145992.

21. Rosenwasser RF, Shah NK, Smith SM, et al. Baseline predictors of central aortic blood pressure: a PEAR substudy. J Am Soc Hypertens. 2014; 8(3): 152-158, doi: 10.1016/j.jash.2013.12.008, indexed in Pubmed: 24629400.

22. Chirinos JA, Franklin SS, Townsend RR, et al. Body mass index and hypertension hemodynamic subtypes in the adult US population. Arch Intern Med. 2009; 169(6): 580-586, doi: 10.1001/archinternmed.2008.611, indexed in Pubmed: 19307521.

23. Kolade OO, O'Moore-Sullivan TM, Stowasser M, et al. Arterial stiffness, central blood pressure and body size in health and disease. Int J Obes (Lond). 2012; 36(1): 93-99, doi: 10.1038/ijo.2011.79, indexed in Pubmed: 21487397.

24. Laursen AS, Hansen ALS, Wiinberg N, et al. Higher physical activity is associated with lower aortic stiffness but not with central blood pressure: the ADDITION-Pro Study. Medicine (Baltimore). 2015; 94(5): e485, doi: 10.1097/MD.0000000000000485, indexed in Pubmed: 25654392.

25. Fletcher EA, Lacey CS, Aaron M, et al. Randomized Controlled Trial of High-Volume Energy Drink Versus Caffeine Consumption on ECG and Hemodynamic Parameters. J Am Heart Assoc. 2017; 6(5), doi: 10.1161/JAHA.116.004448, indexed in Pubmed: 28446495.

26. Karatzis E, Papaioannou TG, Aznaouridis K, et al. Acute effects of caffeine on blood pressure and wave reflections in healthy subjects: should we consider monitoring central blood pressure? Int J Cardiol. 2005; 98(3): 425-430, doi: 10.1016/j.ijcard.2003.11.013, indexed in Pubmed: 15708175.

27. Mandel HG. Update on caffeine consumption, disposition and action. Food Chem Toxicol. 2002; 40(9): 1231-1234, indexed in Pubmed: 12204386.

28. Kreider RB, Kalman DS, Antonio J, et al. International Society of Sports Nutrition position stand: safety and efficacy of creatine supplementation in exercise, sport, and medicine. J Int Soc Sports Nutr. 2017; 14: 18, doi: 10.1186/s12970-017-0173-z, indexed in Pubmed: 28615996

29. Mert KU, Ilgüy S, Dural M, et al. Effects of creatine supplementation on cardiac autonomic functions in bodybuilders. Pacing Clin Electrophysiol. 2017; 40(6): 721-727, doi: 10.1111/pace.13096, indexed in Pubmed: 28436092.

30. Julius S, Pascual AV, London R. Role of parasympathetic inhibition in the hyperkinetic type of borderline hypertension. Circulation. 1971; 44(3): 413-418, doi: 10.1161/01.cir.44.3.413, indexed in Pubmed: 5097443. 